\title{
Local Dialect of Java Community in The Reading of The Qur'an and Its Relationship with The Learning of The Qur'an
}

\author{
$1^{\text {st }}$ Lilik Ummi Kaltsum ${ }^{1}$ \\ \{lilik.ummi@uinjkt.ac.id $\left.{ }^{1}\right\}$ \\ UIN Syarif Hidayatullah, Faculty of Ushuluddin, Jakarta, Indonesia ${ }^{1}$
}

\begin{abstract}
This paper begins with the emergence of qirā'āt (variety of readings) in the hadīth al-ahrūf al-sab'ah. This hadīth explains that the Qur'an was revealed in seven letters. The background of the Arabs at the time the Qur'an was revealed caused the wurūd of the hadīth. Arabs consisting of various clans or clans who have different traditions from one tribe to another in terms of pronunciation of sentences because their dialects and dialects are different. So this paper tries to discuss the local dialects of the Javanese in reading the Qur'an. It can be seen that the Qur'an as a holy book still has cultural values because the Qur'an is revealed to humans, the producers of culture. So, a feasibility if the earthing of the Qur'an, in this case the reading of the text, is greatly influenced by the pronunciation patterns of the local community. The main problem that will be answered is related to the learning patterns. Is the teaching of the Qur'an currently accommodating local dialects in the reading of the Qur'an, as was done by the Apostle in his day.
\end{abstract}

Keywords: Dialect, Local, Qirā'āt (Variety of Readings), Javanese, Indonesian.

\section{Introduction}

'Abd al-Ṣabūr Shāhīn in his book entitled Tārīkh Al-Qur'ān Difā' Didd Hujumāt alIstisyrāq, which has been translated, that in the Mecca period, there were no friends who had difficulty in reading and memorizing the Qur'an. They are all still worth it. Most of them are from the Quraysh. Their contact and contact with the Prophet took place almost every moment. During this period it was possible that there were no differences in the qirā' $\bar{a} t$ (variety of readings) of the Qur'an. Companions of the Prophet Muhammad as a whole are able to read and even memorize the Qur'an well and correctly. Many factors support this ability. Among others, the intensity of their meeting with the Prophet Muhammad, the number is still relatively small, and social situations that have not varied.

After the Holy Prophet and his companions moved to Medina, things changed. The number of Muslims has increased. People flocked to Islam. During this period many friends were sent to various regions within and outside the Arabian Peninsula. The envoys from various regions came and went to Medina. They present different languages and dialects. Medina society itself consists of a mixture of Arabs and Jews. The majority of them are Muslim and others are Jewish. This new era also requires various facilities to support the successful delivery of da'wah and the dissemination of the Qur'an. The goal, so that the Qur'an becomes a constitution for the life of the people of Medina in the new country. Age levels of Muslims also vary. The majority of them are older people who have passed the age of learning and memorizing. Because of this, they have difficulty reading and memorizing the 
Qur'an. The tradition taught by the Prophet Muhammad is the Tabligh tradition, that is, whatever verses received from the Prophet Muhammad must be disseminated to others, not hidden. Whoever receives one or two verses from the Holy Prophet means that he has received much good. He was encouraged to read it according to the level of memorization and in accordance with his dialect, within the boundaries set by the Messenger of Allah.

During this period, the Prophet Muhammad that there were difficulties in reading the Qur'an which were faced by some of his companions. This situation he did not find the Mecca period. He thought about this problem while looking for a solution. Even this anxiety finally got a solution from the owner of kaläm through his meeting with the angel Gabriel. As explained in the hadith which allows him to read the Qur'an with seven letters. Thus, it is permissible to read Qur'an with seven letters is nothing but to eliminate the difficulties faced by people in reading the Qur'an[1].

According to Alif Cahya Setiyadi as he quoted the opinion of Muhammad 'Alī al-Kullī in A Dictionary of Theoretical Linguistics, English-Arabic which states that dialect as a method or method used by humans to express their language and language that shows more geographical, class or the culture of the speaker. Each dialect has characteristics that distinguish it from other dialects in terms of phonology, vocabulary, morphology, and syntax. Dialects will experience changes based on geographical location, political conditions, and also the development of culture that causes the emergence of a language that stands alone. Alif Cahya also added that as he quoted Ramzī Munīr al-Baalbakī in his Dictionary of Linguistic Terms: English-Arabic With Sixteen Arabic Glossaries, it was mentioned that dialect is a style of language, a way of speaking, and the meaning is slightly different from the others. Whereas dialect variety is a group of speakers whose relative numbers differ in a particular place, region or area, both regionally and geographically. Likewise, he quoted Harimurti Kridalaksana's opinion in Linguistic Dictionary which mentioned a broader definition of dialect, which is a form of language variant that varies according to the user, the language variant used by the language group in a particular place (regional dialect / geographical dialect) and is used by certain groups of language groups (social dialects) who live in a certain time (temporal dialect/state of language)[2].

Reading comprehension like this places a language that is understood as a medium used to express ideas, ideas, feelings, experiences. Understanding of this language was raised by alJinnīy who saw language as a social phenomenon[3]. Even Turdgill views language not only as a social phenomenon, but also a cultural phenomenon[4]. This can be understood considering the language used by the community and each society has a certain culture. The Qur'an as a holy book shown to humans must have a certain language as part of culture. Arabic was chosen because the object of the recipient and first user was the Arab community. The main task of the Prophet Muhammad is to ground the divine messages by adjusting local cultures so that messages can be easily understood and applied in life (Q. Ibrāhīm: 4).

In a society, traditions will emerge in both attitude and speech, or commonly known as local wisdom. According to Ade Saptomo as he quoted the opinion of Associate Professor Chatcharee Naritoom from Kasetsart University, Thailand, local wisdom which in English is called Local Wisdom, has the following meaning:

"Local wisdom is the knowledge that discovered or acquired by local people through the accumulation of experiences in trials and integrated with the understanding of surrounding nature and culture. Local wisdom is dynamic by function of created local wisdom and connected to the global situation."

Even this local wisdom was preserved and accommodated in the process of reciting the Qur'an which was exemplified by the Prophet. Research related to the way the Prophet 
accommodated the habits of the Arab tribes in reading the verses of the Qur'an had also been carried out by previous researchers. Among other things Ahsin Sakho Muhammad, entitled The role of Ibn Mujahid in the variety of reading (Peran Ibnu Mujahid dalam Ilmu Qirā'āt). Muhammad Sālim Muhaysin in his book Al-Muqtabas min Al-Lahajāt Al- 'Arabiyyah wa AlQur'aniyyah'. According to these two researchers, it is said that there are tribes which in their daily lives use a lot of "e" as is widely used by the Tamim, the Bedouin tribe in the east of the Arabian Peninsula. This is what eventually became part and phenomenon "imalah" in the reading of the Qur'an. While the Quraysh rarely use it, though there is. From all of these variants of reading the friends can choose for themselves which light reading for them. The phenomenon of reading "imalah", "idham", relief of recitation of hamzah in its various forms, shilah mim jama', turning (sukūn) off the harakat of several harakat in one sentence, etc. is a suitable phenomenon to describe the reason for this relief [6][7]. In this case, Muhammad Sālim Muhaysin added that besides the Tamim tribe, there were other tribes which were accustomed to pronounce "a" incline to "e", namely the Qays, Azad, Tayyi', Bakr bin Wa'il and 'Abd al-Qays. Likewise when saying hamzah. The Tamim say it with a strong pressure, because the distance between their houses is far from each other so that it requires certain pressures in their pronunciation to be heard by their friends. While the Hejaz are along the lines of Mecca and Medina; they are more likely to soften the hamzah by various softening methods, such as moving the community to the previous death letter or replacing it with mad, or discarding it, or others. This is what eventually became part of the phenomenon of reading "tashīl baina baina", ibdātul hamzati biharfi madd, idkhāl alif baina al-hamzatain, hadzf alhamzah, naql harakat al-hamzah ilassākin qablahā, etc[8]

The phenomenon reported from previous studies is sufficient evidence that in the course of history the readings of the verses of the Qur'an illustrated the efforts of the Prophet to accommodate the habits of certain local dialects.

This explanation reinforces that the form of the Qur'an is deeply in contact with culture, in this case local dialects. Prophet Muhammad as the bearer and conveyor of the treatise has strategies for the success of his treatise mission. Oral traditions that develop around him are accommodated in reciting verses of the Qur'an.

Even this historical journey leaves the question if the Prophet Muhammad could be flexible in facing the conditions of society, accommodating local customs. What about the teachers of the Qur'an in Indonesia? Can teachers now also accommodate local dialect habits in reciting verses of the Qur'an? This article is part of the results of research, observation, and direct involvement of the author in the process of earthing the reading of the Qur'an in Indonesian society from 1991 to the present.

\section{Qirā'ät Science and Local Dialogue of the Arab Kabilah}

The origin of the emergence of qirā' $\bar{a} t$ science is the very famous hadìth al-Ahrüf alSab'ah. This hadīth explains that the Qur'an was revealed in seven letters. The background of the Arabs at the time the Qur'an was revealed caused the wurüd of the hadith. Arabs consisting of various clans or puak who have different traditions from one tribe to another in terms of pronunciation of sentences because their accents and dialects are different, so are the conditions of the recipients of the Qur'an that differ from children to adults ( old), and those who are $u m m \bar{\imath}$ (unable to read and write), behind the decline of the hadīth $a l-A h r u ̈ f a l-S a b$ 'ah. It is from these social conditions that the Prophet Muhammad asked Allah for relief in the way 
of reading the texts of the Qur'an. God gives relief in a maximum capacity that is up to seven letters. The scholars from the past until now constantly discuss the true meaning of this hadith. But none of the opinions can provide definitive and convincing answers. Considering that there is no nașs that explains the true meaning of the 7 letters. According to Muhammad Sālim Muhaysin the difference in interpretation of the seven letters reaches more than 40 interpretations. Abū Ubayd al-Qāsim bin Salām $(224 \mathrm{H})$ as he quoted that 7 letters are 7 tribes, namely among others; Sa'id bin Bakr, Nașr bin Mu'āwwiyah, and Thaqīf. Whereas Abū Hatim al-Sijistāni said the 7 tribes were Quraysh, Hudayl, Tamīm, al-Azad, Rabi'ah, Hawāzin, and Sa'id bin Bakr. What can be said here is that the Qur'anic texts can be read with a variety of readings (qirā' $\bar{a} t$ ). All originate from Allah and all aim to lighten up in reading Qur'anic texts. ${ }^{9}$

\section{Get to know the Arab Tribes (Kabilah)}

The Arabs have several tribes (kabilah). Each tribe competes in the power of influence. Each tribe has its own habits, including local dialects. Following are the results of Muhammad Sālim Muhaysin's search for the Arab tribe; First, the Azad tribe is the largest Arab tribe. The naming is based on the main character, al-Azad Ibn Ghauts bin Kahlān. Second, the Azad tribe was a large tribe among al-Adnāniyyah. At first the Azad tribe lived in the city of Nejd, but then after the spread of Islam, they were scattered. Subsequently they lived in Iraq and Kuffah since 19 H. Third, the Tamim tribe was the great tribe of Adnaniyah. The naming is based on Tamim bin Marrah. They live Nejd. Fourth, the Quraysh tribe is a large tribe of descendants from Mālik bin al-Nadar bin Kinānah. Fifth, the Hudhayl tribe is attributed to Hudhayl bin Mudrikah.

The Qur'an as a text necessitates contact with local culture or customs. Search results found there are some local customs or dialects in reading verses of the Qur'an. Muhammad Sālim Muhaysin has classified the verses of the Qur'an based on the dialect of the tribe (Muhammad Sālim Muhaysin 1986, p. 113-131):

\begin{tabular}{|c|c|c|c|}
\hline $\mathrm{Nu}$ & Sentence & Qur'an-Surah & Tribes \\
\hline \multirow[t]{5}{*}{1} & أمانهيم & al-Baqarah & \multirow[t]{5}{*}{ Quraysh } \\
\hline & وسطا & al-Baqarah & \\
\hline & تهنوا & Āli ‘Imrān & \\
\hline & سبيلا & al-Nisā' & \\
\hline & مخصة & al-Mā'idah & \\
\hline \multirow[t]{5}{*}{2} & وباءو ا بغضب & al-Baqarah & \multirow[t]{5}{*}{ Jurhum } \\
\hline & كدأب & Āli ‘Imrān & \\
\hline & تعولوا & al-Nisā' & \\
\hline & كأن لم يغنو ا فيها & al-A'rāf & \\
\hline & أساطير الأولين & al-Anfāl & \\
\hline \multirow[t]{5}{*}{3} & | رشيه & al-Baqarah & \multirow[t]{5}{*}{ Azad Syanu'ah } \\
\hline & تعضلو هن & Hūd & \\
\hline & الرس & al-Furqān & \\
\hline & كا \ـمين & Ghāfir & \\
\hline & من غسلين & al-Hāqqah & \\
\hline \multirow[t]{2}{*}{4} & لاعنتكم & al-Baqarah & \multirow[t]{2}{*}{ Hudhayl } \\
\hline & آناء اليل & Āli ‘Imrān & \\
\hline
\end{tabular}




\begin{tabular}{|c|c|c|c|}
\hline & مر اغما & al-Nisā' & \\
\hline & وجعلكم ملوكا & al-Mā'idah & \\
\hline & 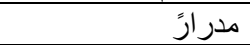 & al-An'ām & \\
\hline 5 & فلارفث & al-Baqarah & Madhhaj \\
\hline & يظاهر من القول & al-Ra'd & \\
\hline & بالو \يد & al-Kahf & \\
\hline & حقبا & al-Kahf & \\
\hline & الخرطوم & al-Kahf & \\
\hline 6 & رغدا & al-Baqarah & Țayyi’ \\
\hline & رجزا & al-Baqarah & \\
\hline & الا من سعة نفسه & al-Baqarah & \\
\hline & ينعسق & al-Baqarah & \\
\hline 7 & تمسره & al-An'ām & Tamīm \\
\hline & يبشرهم & al-Tawbah & \\
\hline & اعصر & Yūsuf & \\
\hline & سر ابيل تقيكم الحمر & al-Naḥl & \\
\hline & متنا بالضم & al-Șāffāt & \\
\hline 8 & اقيضوا & al-Baqarah & Khuzā'ah \\
\hline & افضى & al-Nisā̄ & \\
\hline 9 & وسيدا & Āli ‘'Imrān & Ḥumair \\
\hline & 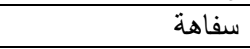 & al-A'rāf & \\
\hline & ففيلنا بينهم & Yūsuf & \\
\hline & 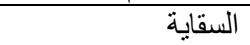 & Yūsuf & \\
\hline & من حمأمسنون & al-Hijr & \\
\hline 10 & ربيون & Āli ‘'Imrān & Ḥaḍramaut \\
\hline & دمرنا & al-Isrā' & \\
\hline & منسأته & Saba' & \\
\hline & الأحقاف & al-Aḥqāf & \\
\hline & وما مسنا من لغب & Qaf & \\
\hline 11 & نحلة & al-Nisā' & Qays 'Ailān \\
\hline & من حرج & al-Mā'idah & \\
\hline & لخاسرون & Yūsuf: 14 & \\
\hline & الأواب & Șad & \\
\hline & تحبيرون & al-Zukhruf & \\
\hline 12 & أن يفتنكم الذين كفروا & al-Nisā’’ & Hawāzin \\
\hline & أفلم ييئس الذين & al-Ra'd & \\
\hline 13 & لا تعلوا & al-Nisā' & Muzainah \\
\hline 14 & ادفعو ا بالعقود & al-Mā'idah & Banu Ḥanīfah \\
\hline & واضمم إلبك & al-Qașaș & \\
\hline & جناحلك من الرهب & al-Qașaș & \\
\hline & تحبرون & al-Zukhruf & \\
\hline 15 & وطفقا & al-A'rāf & Ghassān \\
\hline & بعذاب بئيس & al-A'rāf & \\
\hline 16 & اجتدتها & al-A'rāf & Tsaqīf \\
\hline & 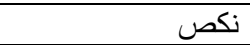 & al-Anfāl & Salīm \\
\hline 17 & 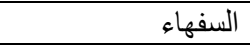 & al-Baqarah & Kinānah \\
\hline
\end{tabular}




\begin{tabular}{|c|c|c|c|}
\hline & |باسئين & al-Baqarah & \\
\hline & وحصورا & Āli ‘Imrān & \\
\hline & لاهـلف & Āli ‘Imrān & \\
\hline & 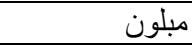 & al-An'ām & \\
\hline 18 & المرجان & al-Raḥmān & al-Yumna \\
\hline 19 & والبحر المسجور & al-Țūr & Āmir bin Hafșah \\
\hline 20 & ما قطعتم من لينه & al-Hasyr & al-'Aws \\
\hline 21 & انفضوا & al-Jumu'ah & al-Khazraj \\
\hline & حتى ينفضوا & al-Munāfiqūn & \\
\hline
\end{tabular}

\section{The Phenomenon of Reading the Qur'an of the Javanese Community}

Indonesia also has a lot of local wisdom or habits that still thrive in some regions in Indonesia. Local wisdom has been born and developed from generation to generation as if surviving and developing by itself. This wisdom has been maintained and grown in the community itself from the eyes of the human heart or the conscience of people who are members of a social unit called the community itself.

As a place of birth of local wisdom, which was originally its scope of validity is among themselves, but as a value of outreach in addition to meeting their needs and the needs of the local community, but also extends to neighboring villages, even the world at large considering the contents are free of space and time. Thus, local wisdom that is now understood to have been able to reach and become a National even become part of the International guidelines (ius societas ius ubi)[10].

Local cultures both attitude and speech also influence the recitation of the verses of the Qur'an. Some people can merge or lose their dialect while some still maintain it.

Community phenomena found by the author include; according to Agung Abdillah, a native of Banyumas and a religious teacher at SD Dua Mei Ciputat, and also Taat Budiono who is also a lecturer in Indonesian Literature at the University of Pamulang (UNPAM), that according to their statement, the Javanese did not recognize the phoneme or sound unit ' $a(\varepsilon)$, they are easier to pronounce $n g a(\hat{\varepsilon})$. So that people in their area when reading the Qur'an and meeting the letter 'ain find it difficult. The pronunciation model in this reading can only be found in certain communities or in rural areas that have become real identities[11]. As in Javanese Tegal contained in the Javanese Tegal-Indonesian Dictionary [12] only has sixteen consonant phonemes, namely $\mathrm{b}, \mathrm{c}, \mathrm{d}, \mathrm{g}, \mathrm{h}, \mathrm{j}, \mathrm{k}, \mathrm{l}, \mathrm{m}, \mathrm{n}, \mathrm{p}, \mathrm{r}, \mathrm{s}, \mathrm{t}, \mathrm{w}, \mathrm{y}$, and five vowel phonemes, namely a, i, u, e, o (Editorial Team 2017, p. 8). Banyumas area, Tegal has a distinctive dialect or dialect commonly known as the ngapak dialect.

According to Rindha Widyaningsih, ngapak language is a typical language that has a different style or style compared to standard Javanese as it is widely known. The language of language has linguistic specificities that are not possessed by standard Javanese. Such advantages, for example, dialects can close their words with sound and noiseless, for example sendok (spoon), endog (egg), angop (evaporate), abab (bad smell), etc.

Language shows the nation. As the proverb illustrates, the language (ngapak) of the father gives a clear description of the mentality of the people and the special characteristics that accompany it. The development of the times brought with it a change in perceptions of the language of the father, so that in daily communication, the language of the father experienced modification and mixing with other languages. Currently, the language of the father began to 
fuse with the urban community, because many residents of Central Java, Banyumas, Tegal and surrounding areas make a living in big cities, then return to their home regions with a "new language" which is the result of a combination of urban languages and the language of the father[13].

This difference has an impact on the way of reciting the Qur'an. Example of QS. al-Fīl [105]: verse 1 there is the word kaifa (كيف). The Javanese people, in particular, have never spontaneously learned specifically to read this combined "ai" vowel to "ae", which is the kaefa tucked in the letter "e". Likewise the word fauqa (فوق) is commonly read by some people with faoqa. This pronunciation is strongly influenced by local dialects who are accustomed to reading "ai" shift to "ae", for example the word "naik" (rising) is read "naek". In addition, the pronunciation that is often heard by some Betawi people when pronouncing

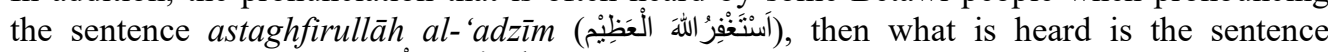

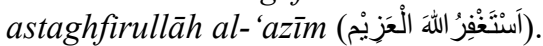

The above description shows that there are various dialects in Javanese society and influence in reading the Qur'an. This influence leaves problems related to the learning process. Can the teachers of the Qur'an accommodate or accept their dialects in the reading of the Qur'an? Bearing in mind that the Prophet Muhammad had done the same thing when facing Arab tribes who had various habits in reciting certain words. In this case, the outline can be divided into 2 patterns. First, the pattern of boarding school, and second, the pattern of the general public. The main figure in spreading the Qur'anic reading model in Indonesia is Sheikh M. Munawwir through his boarding school in Krapyak Yogyakarta. Part of the main material given to the students before reading the Qur'an is an intensive guidance of the recitation of the letter hijaiyah both when fathah-kasrah-dammah or when he was sukün off or turned off. Hijaiyah letters totaling 28 letters are practiced one by one adjusted to makhārij alhurüf (the place where the letters come out) as well as sifat al-hurüf (the nature of each letter).

The teacher or the Sheikh will pay attention to the verbalness of each of his students when imitating the reading that is exemplified by the teacher. In this learning process the teacher will find a variety of reading models. Because, students who study in a boarding school come from various regions with various dialects. Facing this phenomenon the teacher or Sheikh uses the approach and habituation method.

The approach method means the teacher's efforts to approach or recognize the student more closely so that factors will be found that inhibit the difficulty of pronunciation. One factor commonly found is, for example, local dialects. Sundanese people, for example, in their daily dialect are not accustomed to saying the letter "F" or "V" like the letter "P", which is written fitnah "slander" but read pitnah, and the word levis becomes lepis. Some local communities in East Java used to pronounce the letter "Z" to " $\mathrm{J}$ " which is read zakat read jakat. The dialect habits that are formed are difficult to change. Therefore, if the approach method has succeeded in finding out the verbal inhibiting factors, the next step with the habituation method.

The method of formation means that the teacher trains little by little the students' oral form so that they can mimic the teacher's reading. The formation of these letters takes a long time. Because, the teacher must try to change the dialect that has been formed for years according to the makhärij al-hurüf dan șifat al-ḥurüf.

This condition makes the differences in teaching methods and techniques in Indonesia with those outside of Indonesia, especially in Arabic. The main target of the formation method is the students' pronunciation of lafadz or hijaiyah letters the same or approaching the pronunciation of the teacher. This is where dialect fusion occurs. That is, students must open their regional dialect and replace it by reciting the teacher. 
The principle applied in the boarding school is that the Prophet's reading of the letters of the Qur'an has been formulated by the Tajweed scholars. Therefore, the next generation must solve the rules of recitation. In this case there is no leeway as the Prophet Muhammad did to accommodate the readings of the local community. That is, as an educational institution that focuses on Islamic material comprehensively it cannot justify reading the Qur'an whose pronunciation violates the rules of recitation. Different from the learning patterns in the general public. Teaching the Qur'an in the general public will face the complexity of its students' reading models. Especially those who have entered adulthood or who are in certain areas that are very thick in their regional dialect.

The complexity of the community both in ability and in will must be considered by anyone who teaches it. If the Qur'an instructors in the general public equate the standard with the boarding school pattern, it is feared that some of their students will be reduced so that the learning process is stopped.

This condition causes teachers to accommodate the dialects of some of their students with consideration that they remain intact in learning. So, it is considered correct if there is a reading of ghair al-maghdüb nga-laihim (غير المغضوب غليهم). The reading of the pronunciation of $n g a$ (غ) is justified with the consideration that it is not equated with hamzah-'alamin (عالمين). Likewise, the letter ghain (غ) is due to the difficulty of making a sound from the place of the throat, so it is then justified to read "go" or "ngga".

Some people of the Indonesian island of Sumatra are used to vowels "a" and very rarely with vowels "o" so that the pronunciation of khoir (ير) becomes khair. Local scholars accommodate these readings if the pronunciation is not the same as "ha" so it does not sound hair (حير) or (هير).

\section{Conclusion}

1. The Qur'an as a holy book still has cultural value because the Qur'an is revealed to humans, the producers of culture. So, a feasibility if the earthing of the Qur'an, in this case the reading of the text, is greatly influenced by the pronunciation patterns of the local community.

2. The existence of imalah, naql and idham in the science of reading the Qur'an is part of the way the Apostle accommodates local dialects. As the following example illustrates;

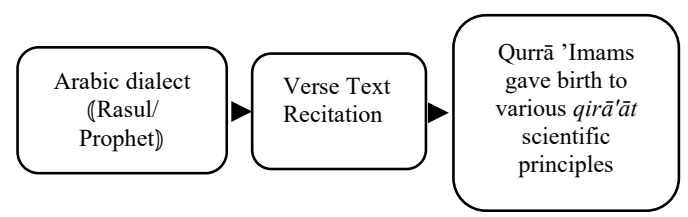


3. The way the Apostle accommodates the dialect of his society can be followed by the Qur'an's teachers on the condition that it is not possible to fully apply the rules of makhārij al-hurüf and șifat al-hurüf hijaiyah.

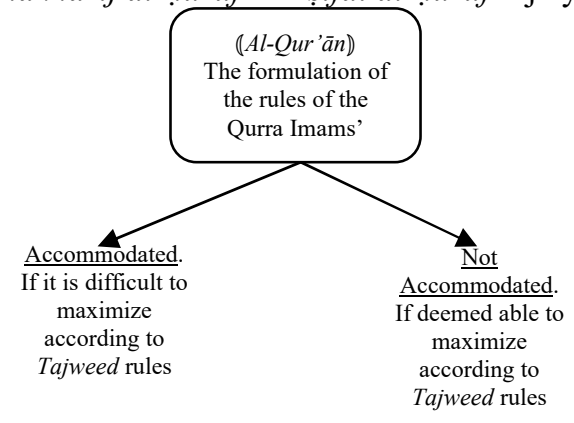

Acknowledgements. This research supported by UIN Syarif Hidayatullah Conference Grant for ICONQUHAS 2019

\section{References}

[1] Shāhīn, 'Abd al-Ṣabūr, 2006. Tārīkh Al-Qur'ān Difā' Didd Hujumāt al-Istisyrāq, terj. Khoirul Amru Harahap dan Akhmad Faozan, Saat Al-Qur'an Butuh Pembelaan: Sebuah Analisis Sejarah, Jakarta: Penerbit Erlangga.

[2] Alif Cahya Setiyadi, "Dialek Bahasa Arab Tinjauan Dialektologis", Jurnal At-Ta'dib, Vol. 6, No. 1, Juni, 2011.

[3] Jinnīy, Abī al-Fatạ̣ 'Uthmān bin, t.t. al-Khashāish, taḥqīi. Muḥammad 'Alī al-Najār, Beirut: Dār al-Kutūb al-Mișriyyah.

[4] Sumarsono dan Partana, Paina, 2002. Sosiolinguistik, Yogyakarta: Sabda.

[5] al-Qațạān, Mannā', 1973. Mabāhhith fì 'Ulūm al-Qur'ān, Surabaya: al-Hidayah.

[6] Muhammad, Ahsin Sakho, 2006. "Peran Ibnu Mujahid dalam Ilmu Qirā'āt", Refleksi: Jurnal Kajian Agama dan Filsafat, Vol. VIII, No. 2.

[7] Muḥaysin, Muḥammad Sālim, 1986. Al-Muqtabas min Al-Lahajāt Al-'Arabiyyah wa AlQur'āniyyah, Kairo: Muassasah Shabāb al-Jāmi'ah.

[8] Muhammad, Ahsin Sakho, 2019. Membumikan Ulumul Qur'an, Jakarta: Penerbit Qaf.

[9] al-Asywaḥ, Șabarī, 1998. I’jāz al-Qirā'āt al-Qur'āniyyah: Dirāsat fì Tārikhì Qirā'āt wa alTijāhāt al-Qurrā', Mesir: Maktabah Wahbah.

[10] Saptomo, Ade, 2014. Budaya Hukum \& Kearifan Lokal: Sebuah Perspektif Perbandingan, Jakarta: FHUP Press.

[11] Agung Abdillah and Taat Budiono, 2019. Interview by M. Najib Tsauri (research member), Jl. Semanggi II RT. 002 RW. 003 No. 71 Kebon Dalem Kel. Cempaka Putih Ciputat Timur Tangerang Selatan, June 12.

[12] Tim Redaksi, 2017. Kamus Bahasa Jawa Tegal-Indonesia, Semarang: Balai Bahasa Jawa Tengah Kementerian Pendidikan dan Kebudayaan, Edisi 2.

[13] Widyaningsih, Rindha, 2014. "Bahasa Ngapak dan Mentalitas Orang Banyumas: Tinjauan dari Perspektif Filsafat Bahasa Hans-Georg Gadamer", Jurnal Ultima Humaniora, Vol II, Nomor 2, September. 